\title{
A Biblio-Systematic Analysis of Factors Affecting the Compliance of Residential Planning Standards and Regulations: A Conceptual Framework
}

\author{
Saaed Awad Abrabba*, Nurwati Badarulzaman, Diana Mohamad, Alaa J. Kadi \\ School of Housing, Building and Planning, Department of Urban \& Regional Planning, University Science Malaysia, Malaysia
}

Received February 3, 2021; Revised March 9, 2021; Accepted April 18, 2021

\section{Cite This Paper in the following Citation Styles}

(a): [1] Saaed Awad Abrabba, Nurwati Badarulzaman, Diana Mohamad, Alaa J.Kadi, "A Biblio-Systematic Analysis of Factors Affecting the Compliance of Residential Planning Standards and Regulations: A Conceptual Framework," Civil Engineering and Architecture, Vol. 9, No. 3, pp. 646-655, 2021. DOI: 10.13189/cea.2021.090308.

(b): Saaed Awad Abrabba, Nurwati Badarulzaman, Diana Mohamad, Alaa J .Kadi (2021). A Biblio-Systematic Analysis of Factors Affecting the Compliance of Residential Planning Standards and Regulations: A Conceptual Framework. Civil Engineering and Architecture, 9(3), 646-655. DOI: 10.13189/cea.2021.090308.

Copyright $\mathrm{C} 2021$ by authors, all rights reserved. Authors agree that this article remains permanently open access under the terms of the Creative Commons Attribution License 4.0 International License

\begin{abstract}
The planning regulations and standards indicate the demands of urbanizations and settlements from a quality point of view and from a big scale to a specific item of the urban parts. The primary purpose of this paper is to create a conceptual framework that serves as a mean to measure the variables influencing the extent of planning compliance in an urban area. The method used is a bibliometric approach as an examination of the area of research. These variables originate from a comprehensive analysis of the literature across countries and time frame from 1976 to 2019 and can affect planning violations positively or negatively by each variable. The findings show five classes of variables which affected the planning deviation in most case studies. The administrative, legislation, social, economic and demographic considerations perform a significant part in ensuring adherence at local and government stage with planning violations. It is important to improve administrative procedures and to revise planning norms and regulations in an attempt to achieve local conditions to deal with planning deviation issues. Cooperation and coordination efforts between authorities and stakeholders are essential to the monitoring and enforcement of planning standards and regulations.
\end{abstract}

Keywords Planning Violation, Non-compliance, Planning Standards, Planning Regulations, Urban Area

\section{Introduction}

The planning violation is defined as any actions which are not according to the planning standards such as deviation from planning regulation and standards. Constructions that do not follow the planning process, encroachment of land use, building density or deviate from the master plan, all these are forms of planning violations [1]. According to [2] researchers came out with several labels and expressions to describe the act of planning violations, such as uncontrolled, unplanned, unorganized and informal and illegal settlements. All these labels described the same situation which is the non-compliance with planning standards and regulations. Alnsour [2] has also noted that the planning compliance level can be at the optimum, middle or at the low level of the compliance with planning standards and regulations. The level of compliance with planning standards and regulations reflect the success of planning system [3].

Planning is indispensable in any urbanization and has a numerous impact on the physical environment and the items connected to it. Planning lexicon includes several terminology such as geographic, regional and urban, these conditions and their laws and norms promote sustainability in addition to improving public health, safety, the presence of urbanization and economic efficiency, etc. [4], [5], [6]; [4]-[6].

Planning regulations lay down planning standards 
pertaining to minimum requirements and criteria for building density, access and road dimensions, maintenance of open spaces, car parking, floor area ratio FAR, building coverage ratio BCR and building heights [7]. Decline the level of compliance with planning standards and regulations not only adversely affects social harmony, residential appearance, but also the atmosphere and, in some instances, endangers people's life [6]. The determination and examination of the variables behind the planning violation was dominant in the planning studies in order to mitigate the escalation of the planning violation. The primary objective of this article is to create a conceptual framework as a measurement tool to identify and examine variables influencing the extent of compliance level in the urban area.

\section{Literature Review}

The planning violation is a result of planning failure [8] and outcome of unanswered demand of housing and planned schemes or further urban development [9] and also it is due to the lack of other option "non-compliance being coercion" [10], option which is legal, appropriate, convenient which is considered the particular conditions in a particular area in real practice [1]. Regarding to real practice, Sundaresan [1] has stated that even the planning encroachment is not directly from planning or it is opposite to planning, but it is still related to it.

The number of publications and studies of the non-compliance with planning standards and regulations has been growing progressively as shown on (figure 1).

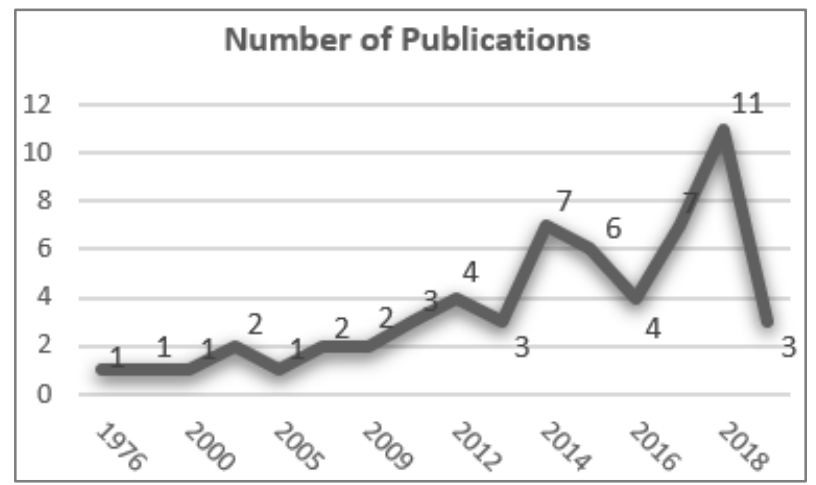

Figure 1. The rise of number of publications of the non- compliance of Planning standards and regulations with time

From a functional point of view of the issue of planning deviations, the components associated with planning violations could share a portion of the responsibility for the occurrence of violations, regardless of the level of impact for each factor. First, a planning violation of the consequences of administrative variables, such as the enforcement of planning laws [11], [12], monitoring system[6], [13], [14]; [6]-[14] lack of trained staff [8], [11], [15];[8]-[15] bureaucracy [7], [16], [17];[7]-[17] lack of coordination[11], [18] and other relevant factors.
Administrative factors are the main factors, based on a bibliometric analysis, which has been shown 73 times in the appropriate journals, approximately $40 \%$ of the total number of other groups of factors as showing in (figure 2).

Second, standards and regulations share a low level of adherence owing to obsolete standards, lack of consideration of the socio-economic character of the society of a specific community, standards imported from colonial or foreign eras or backgrounds not linked to local characters, and a high amount and rigidity of planning [2], [6], [19],[20],[21];[2]-[21].

Third, the variables linked to social characters has also contributed to the planning violation through the public awareness level of the planning standards which could has a positive or negative impact the compliance [3], [22], [23];[3]-[23]. The household size is an important factor which contribute the low level of planning compliance [2], [9], [24], [25];[2]-[25].

Fourth, the economy plays an important role in the compliance level which presented as the income level [1], [24], [26], financial resources and availability of fund [6], [7], [23];[6]-[23], financial facilities which influences the housing provision [2], [27] and infrastructure provision [16].

Finally, the demographic factors such as the rapid growth and migration have been pointed as factors which affect the compliance with planning standards and regulations [11], [14], [28], [29];[11]-[29]. Furthermore, rapid growth may alter the typology of land use, as well as regional planning objectives [30].

All of these factors have a direct or indirect part to play in the stage of planning preparation. The main objective of this research is to establish an expanded conceptual framework to be used as an instrument to assess the level of compliance with planning standards and regulations as a depended variable that has been effected by five sets of independence variables.

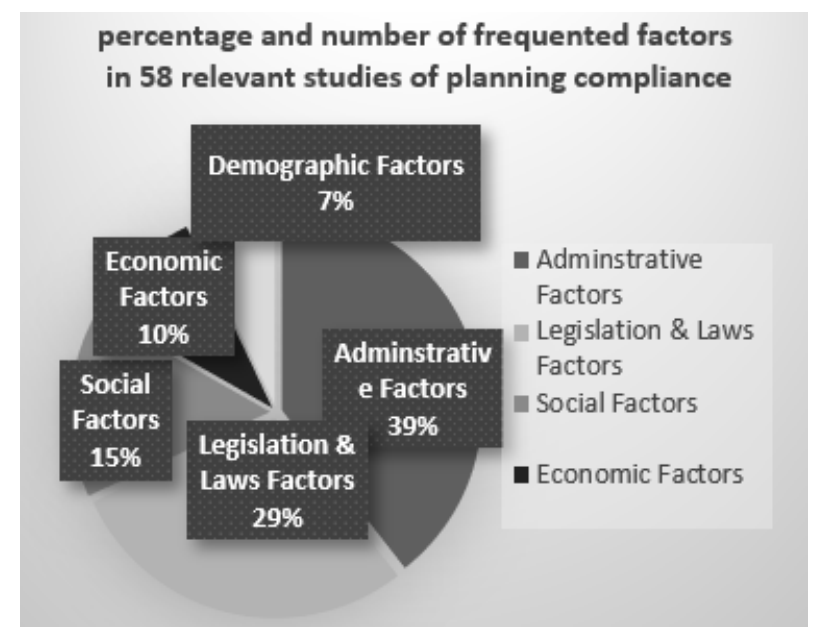

Figure 2. Percentage and number of frequented factors 58 relevant studies of planning compliance 


\section{Architectural Aspect}

Unauthorized housing is not a part of any academic field, but it can be explored in geographical, planning, social, economic and architectural terms [31]. The architectural dimension in urban studies has not been widely considered. The architecture aspect should consider with more links to future urban studies [32]. As far as architectural aspects are concerned, a broad range of designs and arrangements that architects have to deal with to meet the needs and attitudes of the households can result in a challenge for the architects [33]. This challenge is one of the major problem that faces the architects to balance between the planning standards and the people needs which may influence the extent of the compliance with planning standards and regulations. Besides, in many cases, the layouts prepared mainly with little architects' involvement. Therefore, the architectural view does not reflect [22], when layout breaches, architectural expectations will also be at a low rate. For instance, in Egypt, the widespread urban planning deviation, including the impact of architectural style, significantly impacts both urban harmony and the urban peace of the built environment in Cairo due to the absence of control [34]. In Iran, numerous violations of changing green spaces use and gardens and other forms of violations lose precious architecture and cultural heritage and historical values [11]. The breach of the building regulatory framework affected the architectural environments in Riyadh city in Saudi Arabia [35]. Those examples indicated that the architectural aspects have always been affected by deviating planning standards. Even the modern developments that are relatively legal constructions are still not in line with the architectural context, as is the case for Vidyadhar-Nagar-Jaipur India's Walled City model [36]. To sum up this section, it has noted that the architectural aspect is often not mentioned positively if the level of compliance with planning standards is low.

\section{Methodology}

This paper used a combination of two methods to inspect and investigate the related literature; the first is the Bibliometric approach designed from several method in order to examine and evaluate data and information form the perspectives of the quantities of publications and the cites each of them had scored over the period of time [37].The method of bibliometric analysis is a qualitative approach used scientifically based on particular aspect such as titles, authors and citations etc.[38]. This kind of method is helpful to record and monitor the literature growth [39]. Using bibliometric review approach this paper identified the most cited authors, articles and Journals, besides the most used keywords in the planning violation field.

The second approach is the systematic review approach which extracts the content of the selected articles [40],[41],[42];[40]-[42] using this approach this study identified the factors that effecting the compliance level with planning regulations and standards in different parts in the world in order to set an extended conceptual framework to be as a tool to examining and determine the essential variables in any violated urbanization in particular area or in large scale [43]. The databases that selected are Scopus and G.Scholar, then use the most labels and expressions as keywords to search which demonstrated the planning violations dilemma such as violation, compliance, non-compliance and contravention with planning standards and regulations in urban planning. The total quantity of articles, papers and research that relevant to the planning deviation was 336 studies from the both indexes, including duplicated articles which were 65 , then the next procedure excluding the irrelevant ones after reading the abstracts and some of them excluded after reading the whole article and the final relevant studies were 58 studies.

\section{Results}

\subsection{The Most Important Articles and Authors on the Planning Violation}

From the bibliometric study, the most important published study based on the number of citations is "the compliance with urban development and planning regulations" which is conducted in 2000 as Ibadan, Nigeria a case study, followed by article published in 2016 which study the compliance of land cover change with municipal land use planning, then the other important article conducted by Alnsour [2] which has the first framework to examining the factor effecting residential standards in the city of Old Salt, Jordan and it has dealt only with the residential standards.

The (Table 1) illustrates the most five important articles that conducted on the non-compliance with planning standards besides the top authors who focus on the issue of planning deviation. The result also illustrates the most important key words that has been used on the non-compliance which was ordered based on the number of frequency (Table 2). 
Table 1. Top article and authors on Non-compliance with planning standards

\begin{tabular}{|c|c|c|c|c|}
\hline Article Title & Author Name & Journal Name & Year & Cite No. \\
\hline $\begin{array}{l}\text { Compliance with urban development and planning } \\
\text { regulations in Ibadan, Nigeria }\end{array}$ & BC Arimah, D Adeagbo & Habitat International & 2000 & 86 \\
\hline $\begin{array}{l}\text { Compliance of land cover changes with municipal land } \\
\text { use planning: Evidence from the Lisbon metropolitan } \\
\text { region (1990-2007) }\end{array}$ & $\begin{array}{l}\text { P Abrantes, I Fontes, E } \\
\text { Gomes, J Rocha }\end{array}$ & Land Use Policy & 2016 & 44 \\
\hline $\begin{array}{l}\text { Factors affecting compliance with residential standards in } \\
\text { the city of Old Salt, Jordan }\end{array}$ & J Alnsour, J Meaton & Habitat International & 2009 & 36 \\
\hline $\begin{array}{l}\text { Land use regulations, compliance and land markets in } \\
\text { Argentina }\end{array}$ & P Monkkonen, L Ronconi & Urban Studies & 2013 & 31 \\
\hline $\begin{array}{l}\text { Determinants of low land use planning regulation } \\
\text { compliance rate in Ghana }\end{array}$ & $\begin{array}{l}\text { KGB Awuah, FN } \\
\text { Hammond }\end{array}$ & Habitat International & 2014 & 24 \\
\hline $\begin{array}{l}\text { The owner occupier democracy and violation of building } \\
\text { by-laws }\end{array}$ & RW Rukwaro & Habitat International & 2009 & 16 \\
\hline
\end{tabular}

Table 2. The most used keywords on the non-compliance with planning studies

\begin{tabular}{cc}
\hline Keyword & Number of using \\
\hline Compliance & 10 \\
\hline Building contravention & 5 \\
\hline Violation & 4 \\
\hline Non-compliance & 2 \\
\hline Planning regulation & 2 \\
\hline Residential standards & 2 \\
\hline Development control & 2 \\
\hline Enforcement & 2 \\
\hline
\end{tabular}

\subsection{The Five Groups of Factor and Its Items}

After inspecting all the relevant articles selected in April 2019 and applying systematic review approach in which the study determined the factors affecting the level of compliance with planning standards and regulations from different areas and time. The results are listed (Table 3 ) and classified into five groups of factors (Figure 2) and each individual group contain several variables, these variables has affect to the violation level in a negative or positive effectiveness. The classification of these 5 group is based on two studies which use this category to classify the variables into several groups [2], [28]. Alnsour has classified the variables into three categories which are socio-economic factors, administrative practices and the uncertainty of residential standards. Abubaker has used the same categories and added the fourth category of factors which is the demographic variable. In this study, the conceptual framework work combined the two frameworks and divided the socio-economic factors into two groups as social factors and economic factors. In addition, on the basis of the literature review and the bibliometric study, the factors which added to the classified groups are based on the literature review referred to as social, economic, administrative, legislative, etc. All these classes of factors are defined as independent variables which affect the dependency variable, which is the extent of compliance level with planning standards and regulations.

This conceptual framework (Figure 3) is used as an instrument to examine and determine the variables affecting the level of compliance. Each variable could have several phrases and marks with the same significance and impact as used in the literature review, such as the bureaucratic variable can be found as a rigid method, a long time to obtain title or license, otherwise the enforcement variable can be recognized as an application, and the income level can be used in other categories such as poverty, etc. From the literature review, it can be seen that the planning violations do not concern and require only the planning authorities, but also a multi-faceted problem requiring the involvement of a number of performers to address such issues as planning violation, social, economic, legislative, cooperation to deal with as they have correlations between them and efficiency declines in the degree of compliance. 
Table 3. Percentage and number of frequented factors in 58 relevant studies of planning compliance with standards

\begin{tabular}{|c|c|c|c|}
\hline & Category of group of Factors & Percentage of repeated & $\begin{array}{c}\text { The number of frequented factor } \\
\text { in literature review }\end{array}$ \\
\hline \multirow{2}{*}{\multicolumn{2}{|c|}{$\begin{array}{c}\text { Group 1 } \\
\text { Administrative Factors }\end{array}$}} & $40 \%$ & \multirow{2}{*}{73} \\
\hline & & Other expression of the factor & \\
\hline 1. & Monitoring & Control system/Supervision & 15 \\
\hline 2. & Bureaucracy & $\begin{array}{l}\text { Rigid process/long time obtaining } \\
\text { title or permit }\end{array}$ & 13 \\
\hline 3. & Enforcement & Implementation & 12 \\
\hline 4. & Lack of coordination & Corporation / collaboration & 12 \\
\hline 5. & Trained staff / lack of staff & Lack of trained staff/lack of staff & 11 \\
\hline 6. & Corruption & & 7 \\
\hline 7. & Centralization & $\begin{array}{c}\text { Weak power at domestic/municipal } \\
\text { level }\end{array}$ & 3 \\
\hline \multirow{2}{*}{\multicolumn{2}{|c|}{$\begin{array}{c}\text { Group } 2 \\
\text { Legislation \& Laws factors }\end{array}$}} & $28 \%$ & \multirow{2}{*}{53} \\
\hline & & Other expression of the factor & \\
\hline 1. & Uncertainly & General ignorance of standards & 12 \\
\hline 2. & Outdated standards & Old version & 9 \\
\hline 3. & Plot size & More living space & 9 \\
\hline 4. & Sanction/penalties action & $\begin{array}{l}\text { Postpone of penalty /delay } \\
\text { demolition action }\end{array}$ & 9 \\
\hline 5. & Rigid and High & Inadequate regulations & 8 \\
\hline 6. & Colonial input & $\begin{array}{l}\text { Foreigner background/imported } \\
\text { rules }\end{array}$ & 6 \\
\hline \multirow{2}{*}{\multicolumn{2}{|c|}{$\begin{array}{c}\text { Group } 3 \\
\text { Social Factors }\end{array}$}} & $15 \%$ & \multirow{2}{*}{28} \\
\hline & & Other expression of the factor & \\
\hline 1. & Awareness level & $\begin{array}{c}\text { Public } \\
\text { /builders/developers/planners lack } \\
\text { of awareness }\end{array}$ & 13 \\
\hline 2. & Household size & Family size & 10 \\
\hline 3. & Culture /life style & $\begin{array}{l}\text { The living activities/traditional } \\
\text { style of life }\end{array}$ & 3 \\
\hline 4. & Kinship \& tie personal interest & & 2 \\
\hline \multirow{2}{*}{\multicolumn{2}{|c|}{$\begin{array}{c}\text { Group } 4 \\
\text { Economic Factors }\end{array}$}} & $10 \%$ & \multirow{2}{*}{18} \\
\hline & & Other expression of the factor & \\
\hline 1. & Finance & Fund/financial support & 7 \\
\hline 2. & Housing shortage & $\begin{array}{l}\text { High demand with low supply of } \\
\text { housing/planned subdivision }\end{array}$ & 4 \\
\hline 3. & Infrastructure provision & $\begin{array}{c}\text { Poor utilities/absent of basic and } \\
\text { necessary services }\end{array}$ & 3 \\
\hline 4. & Change use for income & & 4 \\
\hline \multirow{2}{*}{\multicolumn{2}{|c|}{$\begin{array}{c}\text { Group } 5 \\
\text { Demographic Factors }\end{array}$}} & $7 \%$ & \multirow{2}{*}{13} \\
\hline & & Other expression of the factor & \\
\hline 1. & Rapid growth & & 7 \\
\hline 2. & Migration & & 6 \\
\hline
\end{tabular}




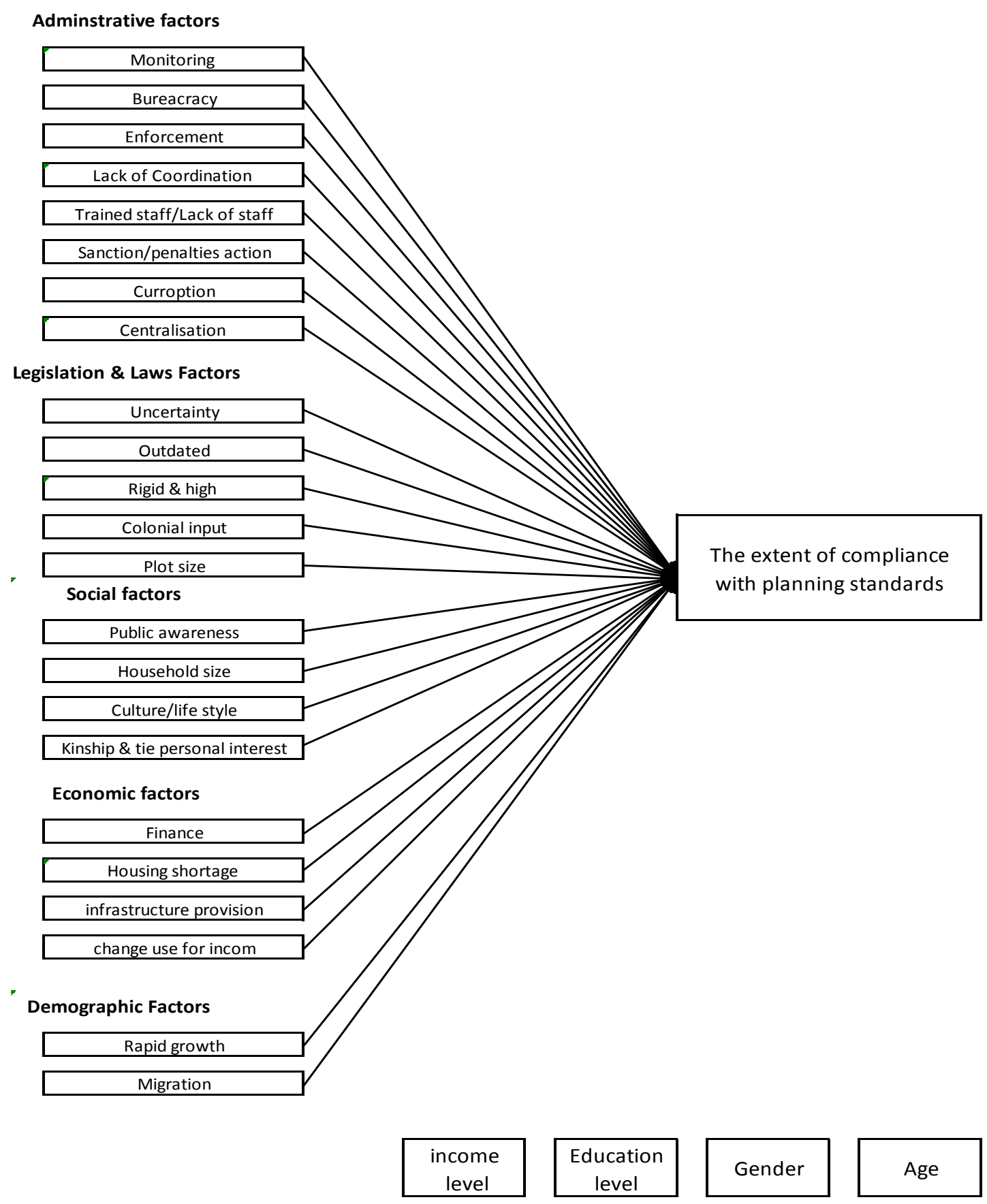

Figure 3. The conceptual framework

\subsection{The Moderating Variables}

The moderators were found which adjusting the relationship between the independence and dependence variables as illustrated in (Table 4). The income level is a vital factor [2], [9], [18], [19], [24];[2]-[24] and it found as Independent variable in Alnsour [2] study, but in this study it is set as moderator as it is more convenient in this context because the moderating variable moderate the independent variable effect in the study [44], based on the concept of the moderating variable, which is designed to reduce the impact of independent variables used in this research to define the moderating variable as they adjust the connection between independent and dependent variables. In addition, the connection between the dependent variable (the extent of compliance level with planning standards) and the independent variables (the level of income) has affected the amount of conformity based on the literature review. In fact, it has been cited as a significant variable 15 times, followed by three other moderating variables, namely the level of education, gender and age of respondents. 
Table 4. The moderating variables

\begin{tabular}{ccc}
\hline The moderator & Quantity & Percentage \\
\hline Income level / poverty & 15 & $53 \%$ \\
\hline Education level & 7 & $25 \%$ \\
\hline Gender & 3 & $11 \%$ \\
\hline Age & 3 & $11 \%$ \\
\hline
\end{tabular}

\subsection{Forms of Planning Violation}

Table 5 shows the various types of planning violations and urban planning situations in different counties and regions. The forms of planning violations vary from one area to another. These forms of violations are divided into four categories: residential building violations, land use violations, public land use violations, and unauthorized locations.

\section{Discussion}

Table 5. Forms of planning violation the urban planning situations in different countries and regions
Based on the bibliometric analysis carried out as a method in this study of the relevant publications of non-compliance with planning standards and regulations, the findings of the factors that affected the level of compliance planning across countries and the timeframe were therefore significant, which attempted to give an overall view of the significant factors that contributed to the decline. The majority of the case studies are liable and relied on the amount of respondents, first of all on the administration of the planning authorities, including monitoring, bureaucracy, enforcement and other factors. This outcome was comparable to the findings of Arku [6] as it pointed out that the respondents emphasized that the administrative variables are the most and the most important triggers of the cases. Secondly, planning standards and regulations, including uncertain, obsolete, rigid and high standards. It is essential to note that the standards and regulations have been continuously stated by researchers for 53 times, and this factor may be significant, as it is the primary cause and not as the administrative factors that are generated by the ambiguity of the existing standards.

\begin{tabular}{|c|c|c|c|c|c|c|c|c|c|c|c|c|c|c|c|c|c|c|c|c|c|c|c|c|c|c|c|c|c|c|c|c|}
\hline \multirow[b]{2}{*}{ Country } & \multirow[b]{2}{*}{ Author-Year } & \multicolumn{15}{|c|}{$\begin{array}{l}\text { Forms of Residential building violation/ } \\
\text { housing modification }\end{array}$} & \multicolumn{5}{|c|}{$\begin{array}{l}\text { Forms of land Use } \\
\text { Violation-Zoning }\end{array}$} & \multicolumn{5}{|c|}{$\begin{array}{l}\text { Forms of Public } \\
\text { land use violations }\end{array}$} & \multicolumn{6}{|c|}{$\begin{array}{l}\text { Unauthorised places } \\
\text { out of the urban plan }\end{array}$} \\
\hline & & 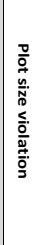 & 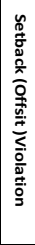 & 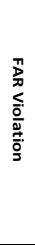 & 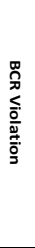 & 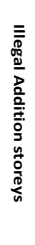 & 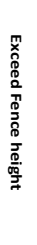 & 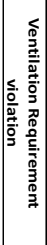 & 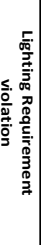 & 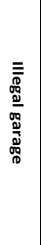 & 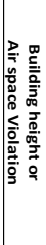 & 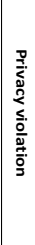 & 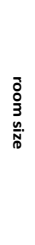 & 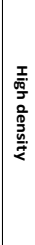 & 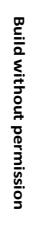 & 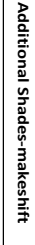 & 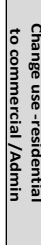 & 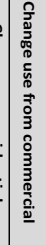 & 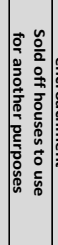 & 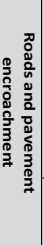 & 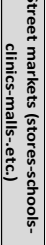 & 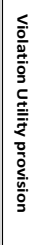 & 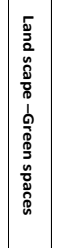 & 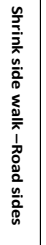 & & & 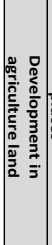 & 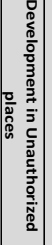 & & 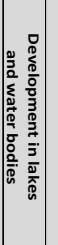 & 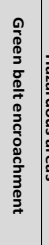 & 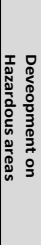 \\
\hline Iran & Sarkheyil (2012) & $\bullet$ & $\bullet$ & $\bullet$ & $\bullet$ & $\bullet$ & $\bullet$ & $\bullet$ & & & & & & $\bullet$ & $\bullet$ & & $\bullet$ & & & & & & & & & $\bullet$ & & & & & & \\
\hline Chana & Arku (2016) & $\bullet$ & $\bullet$ & $\bullet$ & & & & & & & & & & & $\bullet$ & & & & & & & $\bullet$ & & & & & & $\bullet$ & & & & \\
\hline Nigeria & Arimah (2000) & & $\bullet$ & $\bullet$ & - & & $\bullet$ & $\bullet$ & $\bullet$ & & $\bullet$ & & $\bullet$ & & & $\bullet$ & - & & & & $\bullet$ & $\bullet$ & & $\bullet$ & & & & & & & & \\
\hline Kenya & \begin{tabular}{|l} 
Rukwaro (2009) \\
\end{tabular} & & $\bullet$ & $\bullet$ & $\bullet$ & & & $\bullet$ & $\bullet$ & & $\bullet$ & $\bullet$ & $\bullet$ & & & & - & & & & & & & & & & & & & & & \\
\hline India & Sundaresan (2017) & & $\bullet$ & $\bullet$ & & & & & & & $\bullet$ & & & $\bullet$ & $\bullet$ & & $\bullet$ & & & $\bullet$ & $\bullet$ & & $\bullet$ & $\bullet$ & & & $\bullet$ & & & $\bullet$ & $\bullet$ & \\
\hline India & Jawaid (2018) & $\bullet$ & $\bullet$ & $\bullet$ & $\bullet$ & & & $\bullet$ & $\bullet$ & & $\bullet$ & & & & & & $\bullet$ & & & $\bullet$ & & $\bullet$ & & & & & & & & & & \\
\hline Belgrade & Zegarac (1999) & & $\bullet$ & $\bullet$ & & $\bullet$ & & & & $\bullet$ & $\bullet$ & & $\bullet$ & $\bullet$ & & $\bullet$ & - & & & • & $\bullet$ & $\bullet$ & & - & & & & & & & & \\
\hline Greece & |loannidis (2009) & & & & & & & & & & & & & & & & & & & & & & & & & & $\bullet$ & & & & & \\
\hline S. Africa & Few (2009) & & & & & & & & & & & & & & & & & $\bullet$ & & & & & & & & & & $\bullet$ & & & & \\
\hline Iran & Hajialirezalou (2018) & $\bullet$ & $\bullet$ & $\bullet$ & - & $\bullet$ & & & & $\bullet$ & $\bullet$ & & $\bullet$ & & $\bullet$ & $\bullet$ & $\bullet$ & & & & & $\bullet$ & & & & - & & & & & & \\
\hline Iran & Sarkheyil (2013) & $\bullet$ & $\bullet$ & $\bullet$ & & $\bullet$ & & & & & & & & $\bullet$ & $\bullet$ & $\bullet$ & - & & & & $\bullet$ & & - & & & $\bullet$ & & & & & & \\
\hline Kenya & Omollo (2018) & & & $\bullet$ & - & $\bullet$ & & & & & & & & $\bullet$ & & & - & & & & & & & & & & & & & & & \\
\hline India & Boob (2014) & & & $\bullet$ & $\bullet$ & & & & & & & & & & & $\bullet$ & $\bullet$ & & & $\bullet$ & & & & $\bullet$ & $\bullet$ & & & & & & & \\
\hline Jordan & Alnsour (2009) & & $\bullet$ & $\bullet$ & & $\bullet$ & $\bullet$ & $\bullet$ & & & & & & & & & & & & & & & & & & & & & & & & \\
\hline Portugal & Calor (2015) & & & & & & $\bullet$ & & & & & & & & & & $\bullet$ & & & & & & & & & & $\bullet$ & & $\bullet$ & & & \\
\hline Ghana & Offei (2018) & $\bullet$ & & & - & & $\bullet$ & & & & & & & & & & & & & - & & & & & & & & & & & & \\
\hline Bangladesh & Nahrin (2008) & & $\bullet$ & $\bullet$ & & $\bullet$ & & $\bullet$ & & & $\bullet$ & & & & & & - & & & & & $\bullet$ & - & & & & & & & & & \\
\hline Nigeria & Wahab (2018) & & $\bullet$ & & $\bullet$ & & & & & & & & & & & & & & & & & & & & & & & & & $\bullet$ & & \\
\hline Tanzania & John (2018) & & & & & & & & & & & & & & & & & & & & & & & & & & & & & & & - \\
\hline Iran & Shahraki (2017) & & & & & & & & & & & & & & & & & & & & & & & & & & & $\bullet$ & & & & \\
\hline Tanzania & Kombe (2005) & & & & & & & & & & & & & & & & & & & & & & & & & & & $\bullet$ & & & & \\
\hline Tanzania & Fekade (2000) & & & & & $\bullet$ & & & & & & & & $\bullet$ & & & $\bullet$ & & & & & & & & & & & & & & & \\
\hline Ghana & Kleemann (2017) & & & & & & & & & & & & & & & & & & & & & & & & & & & & - & & & \\
\hline
\end{tabular}


Followed by social, economic and demographic factors as shown in (Figure 2). In fact, when we look at these factors, we can see that these factors are grouped into two segments, the first, the real factors behind the act of non-compliance, the second, the subsequent and the factors that have caused by the actual causes. In addition, the solution of the real causes and factors will eventually lead to the disappearance of the other factors , the division of the factors into the main factors and subsequent factors has not been identified in the literature review and may be considered as a gap to be filled in the future. This gap in the classification of the factors into two sections is important to know the real reasons that need to be fixed other than the subsequent one. Although factors have been categorized based on perceived and objective factors [45], more realistic studies are still required to classify such aspects into main and consequent factors.

To sum up this section, we can derive from this evaluation research that, in order to resolve or at least mitigate the non-compliance with planning standards, the updated, suitable standards and regulations that took into account all the socio-economic circumstances of local conditions are needed, where this will be reflected in monitoring and enforcement as a relief from stress because of the factors behind the non-compliance.

\section{Conclusion}

As the noncompliance with planning regulations affected by a number of factors that are not completely regulated by the planning authorities, the processes and the proper approach to tackling this problem can only operate when all of these elements and performers cope with it following the investigation of all the conditions in a specific location at a specific moment. Each factor has an impact on the level of compliance, and its impact varies from urbanization to urbanization, and each factor could have an impact on a single, dual or even tripartite issue, such as the level of income that could, in a number of ways, lead to a planning violation. Based on the bibliometric study, the most affecting group of factors are the administration factors and the legislation and the standards, which means that these are essential factors that require updating and revision from time to time before the other aspect such as social and economic factors since the economy and social situation is often considered as a fait accompli that would be difficult to change in the near future. As the planning standards take architectural dimensions and adopt them with planning standards, the architectural aspect has always been adversely affected by planning standards contravention. Concerning the planning violations, the architectural features are often adversely stated. The division of factors into main causes and subsequent factors is needed as it is missing from the literature review that required further research as it is important to address the issue of non-compliance with planning standards and regulations.

\section{REFERENCES}

[1] J. Sundaresan, "Urban planning in vernacular governance: Land use planning and violations in Bangalore, India," Prog. Plann., no. November 2016, pp. 0-1, 2017. https://doi.org/10.1016/j.progress.2017.10.001

[2] J. Alnsour and J. Meaton, "Factors affecting compliance with residential standards in the city of Old Salt, Jordan," Habitat Int., vol. 33, no. 4, pp. 301-309, 2009. https://doi.org/10.1016/j.habitatint.2008.08.003

[3] K. G. Baffour Awuah and F. N. Hammond, "Determinants of low land use planning regulation compliance rate in Ghana," Habitat Int., vol. 41, pp. 17-23, 2014. https://doi.org/10.1016/j.habitatint.2013.06.002

[4] N. A. Boamah, C. Gyimah, and J. K. Bediako Nelson, "Challenges to the enforcement of development controls in the Wa municipality," Habitat Int., vol. 36, no. 1, pp. 136142, 2012. https://doi.org/10.1016/j.habitatint.2011.06.010

[5] K. M. Racheal Njeri Mugo1, David N. Kuria2, 3, "Assessing the Compliance of Physical Plans using GIS and Remote Sensing: A Case of Olkalou Town," Int. J. Sci. Res., vol. 3, no. 12, pp. 925-934, 2014. http://41.89.227.156:8080/xmlui /handle/123456789/455

[6] G. Arku, K. O. Mensah, N. K. Allotey, and E. Addo Frempong, "Non-compliance with building permit regulations in Accra-Tema city-region, Ghana: exploring the reasons from the perspective of multiple stakeholders," Plan. Theory Pract., vol. 17, no. 3, pp. 361-384, 2016. https://doi.org/10.1080/14649357.2016.1192216

[7] N. G. A. Adamolekun, M. O., A. J. Isiwele, "AN ASSESSMENT OF THE LEVEL OF COMPLIANCE WITH DEVELOPMENT CONTROLSTANDARDS AND HOUSING POLICY IN NIGERIA. : A CASE STUDY OF ESAN WEST LOCAL GOVERNMENT AREA OF EDO STATE," J. Environ. Stud., vol. 2, no. 2, pp. 27-35, 2017.

[8] E. Offei, M. Lengoiboni, and M. Koeva, "Compliance with Residential Building Standards in the Context of Customary Land Tenure System in Ghana," plaNext - next Gener. Plan., vol. 6, pp. 25-45, 2018. https://doi.org/10.24306/plnxt.2018 .06 .002

[9] E. Sarkheyli and M. Rafieian, "Assessing Tehran's Urban Structure Effects on Non-Compliance with FAR Regulations," Arman. Archit. Urban Dev., vol. 6, no. 10, pp. 237-252,

2013.https://www.researchgate.net/publication/309456651 Assessing_Tehran's_Urban_Structure_Effects_on_Non-Co mpliance_with_FAR_Regulations [Google Scholar]

[10] C. Rakodi, "Forget planning, put politics first? Priorities for urban management in developing countries Carole," City, vol. 3, no. 3, pp. 209-223, 2001. https://doi.org/10.1016/S0 303-2434(01)85029-7

[11] M. H. Hajialirezalou, "Building Contraventions in Tehran and Its Control by the Municipality," Landsc. Archit. art, vol. 12, no. 12, pp. 95-104, 2018. https://doi.org/10.22616/j.lan 
darchart.2018.12.10

[12] W. O. Omollo, P. O. Hayombe, and F. O. Owino, "Compliance with Physical Planning Standards by Residential Developments in Kisii Town, Kenya," Archit. Res., vol. 8, no. 2, pp. 62-73, 2018. https://doi.org/10.5923/j.arch.20180802.03

[13] B. C. Arimah and D. Adeagbo, "Compliance with urban development and planning regulations in Ibadan, Nigeria," Habitat Int., vol. 24, no. 3, pp. 279-294, 2000. https://doi.org/10.1016/S0197-3975(99)00043-0

[14] K. Nahrin, "Violation of Land Use Plan and Its Impact on Community Life in Dhaka City," Jahangirnagar Plan. Rev., vol. 6, no. June, pp. 39-48, 2008.

[15] S. McKay and G. Ellis, "Reparation or retribution: An investigation into regulatory compliance in planning," Environ. Plan. A, vol. 37, no. 7, pp. 1249-1262, 2005. https://doi.org/10.1068/a36288

[16] P. Monkkonen and L. Ronconi, "Land Use Regulations, Compliance and Land Markets in Argentina," Urban Stud., vol. 50, no. 10, pp. 1951-1969, 2013. https://doi.org/10.1177/0042098012471982

[17] P. Abrantes, I. Fontes, E. Gomes, and J. Rocha, "Compliance of land cover changes with municipal land use planning: Evidence from the Lisbon metropolitan region (1990-2007)," Land use policy, vol. 51, pp. 120-134, 2016. https://doi.org/10.1016/j.landusepol.2015.10.023

[18] D. G. Pampanga, M. R. Majid, and C. R. Angel, "Assessing the Compliance of Balanced Housing Policy in the Philippines: The Case of Davao City," Int. J. Built Environ. Sustain., vol. 2, no. 2, pp. 93-100, 2015. https://doi.org/10.11113/ijbes.v2.n2.63

[19] E. Srkheylai, A. Sharifi, M. Rafieian, M. reza Bemanian, and A. Murayama, "An investigation of the reasons for non-compliance with FAR regulations in Tehran," Cities, vol. 29, no. 4, pp. 223-233, 2012. https://doi.org/10.1016/j.cities.2011.09.004

[20] U. Ituen, I. Johnson, R. Planning, and R. Planning, "Securing Land Title / Ownership Rights: A Survey of the level of Compliance with Land Registration in Akwa Ibom State, Nigeria," Res. Humanit. Soc. Sci. ISSN, vol. 4, no. 1, pp. 6979, 2014

[21] G. E. D. OMUTA, “CAMOUFLAGE, CONTRAVENTION OR CONNIVANCE towards an Evaluation of Development Control in Bendel State, Nigeria," Third World Plann. Rev., vol. 9, no. 2, pp. 135-153, 1987. https://doi.org/doi.org/10.3828/twpr.9.2.g161301232038354

[22] T. N. Boob and Y. R. M. Rao, "Zoning within Plot - An Approach to Land Sub Division to Control Violation of Development Control Rules," Int. J. Multidiscip. Curr. Res., vol. 2, no. 4, pp. 48-59, 2014.

[23] I. Calor, I. Fontes, and P. Abrantes, "Monitoring Planning Compliance. Assessment of land use changes in Lezíria do Tejo region, Portugal," in 29th Annual AESOP 2015 Congress, July 13-16, 2015, Prague, Czech Republic, 2015, no. 7, pp. 1104-1116. Retrieved from http://aesop2015.webnode.cz/

[24] R. W. Rukwaro, "The owner occupier democracy and violation of building by-laws," Habitat Int., vol. 33, no. 4, pp. 485-498, 2009. https://doi.org/10.1016/j.habitatint.2009.03. 004

[25] J. M. Lusugga Kironde, "The regulatory framework, unplanned development and urban poverty: Findings from Dar es Salaam, Tanzania," Land use policy, vol. 23, no. 4, pp. 460-472, 2006. https://doi.org/10.1016/j.landusepol.2005.0 7.004

[26] R. John, "Compliance with Planning Regulations in Hazardous Areas and its Impacts A Case of Msasani Bonde la Mpunga in Dar es Salaam City, Tanzania," African J. L. Policy Geospatial Sci., pp. 41-52, 2018.

[27] E. E. Atamewan, "Factors Affecting Implementation and Compliance with Housing Standards for Sustainable Housing Delivery in Bayelsa State, Nigeria," Eur. Sci. J. ESJ, vol. 15, no. 3, pp. 210-222, 2019. https://doi.org/10.19044/ esj.2019.v15n3p210

[28] M. Abubakar, M. Lizam, and A. M. B. Yassin, "A Review on the Models of Compliance with Residential Development Standards in Nigeria," 2nd Int. Conf. Technol. Manag., Bus. Entrep., no. 12, pp. 522-531, 2013.

[29] M. B. Jimoh, B. A., Al-Hasan, A.Z., Imimole, W.O., and Ahmed, "Contravention of Development Control Measures in Auchi , Edo State , Nigeria," Appl. Sci. Reports, pp. 181184, 2017. https://doi.org/10.1007/s00330-002-1650-5

[30] I. Wunarlan, S. Soetomo, and I. Rudiarto, "Typology of peri-urban area based on physical and social aspects in Marisa, Indonesia," Civ. Eng. Archit., vol. 8, no. 5, pp. 984992, 2020. https://doi.org/10.13189/cea.2020.080525

[31] A. Walker, "The social context of built form: The case of informal housing production in Mexico City," no. 114, p. 31, 2001.

[32] J. A. Mohammad, "Planning and Managing the Built Environment in the Context of Compliance with Residential Standards in Jordan," 2006.

[33] A. A. Omar, "AN EVALUATION OF LOW INCOME HOUSING PROJECT IN DEVELOPING COUNTRIES CASE STUDY," University of Salford, Salford, 2003.

[34] A. S. Abd Elrahman and R. A. Mahmoud, "The post-revolutionary effect on the urban harmony of Cairo's built environment in relation to the collective memory of the population: Urban context of the 'after revolution' between contravention and elaboration," Ain Shams Eng. J., vol. 7, no. 4, pp. 1099-1106, 2016. doi:10.1016/j.asej.2015.10.007

[35] S. E. Aboshiqah, "Development of Spatial Inspection Methods to Support Building Inspections and Compliance," Curtin University, 2014.

[36] M. F. Jawaid, S. Pipralia, and A. Kumar, "Review of environment responsiveness of building regulations in Jaipur,” J. Urban Manag., no. February, pp. 0-1, 2018.

[37] J. L. Hung, "Trends of e-learning research from 2000 to 2008: Use of text mining and bibliometrics," Br. J. Educ. Technol., vol. 43, no. 1, pp. 5-16, 2012. https://doi.org/10.1111/j.1467-8535.2010.01144.x

[38] A. Hussain, N. Fatima, and D. Kumar, "Bibliometric analysis of the 'Electronic Library' journal (2000-2010)," Webology, vol. 8, no. 1, pp. 1-11, 2011. Retrieved from 
www.webology.org/2011/v8n1/a87.html

[39] A. Abdi, N. Idris, R. M. Alguliyev, and R. M. Aliguliyev, "Bibliometric Analysis of IP\&M Journal (1980-2015)," J. Scientometr. Res., vol. 7, no. 1, pp. 54-62, 2018. https://doi.org/10.5530/jscires.7.1.8

[40] D. Ettehad et al., "Blood pressure lowering for prevention of cardiovascular disease and death: A systematic review and meta-analysis," Lancet, vol. 387, no. 10022, pp. 957-967, 2016. https://doi.org/10.1016/S0140-6736(15)01225-8

[41] S. C. Ng et al., "Worldwide incidence and prevalence of inflammatory bowel disease in the 21 st century: a systematic review of population-based studies," Lancet, vol. 390, no. 10114, pp. 2769-2778, 2017. https://doi.org/10.1016/S0140 $-6736(17) 32448-0$

[42] B. W. Roberts, J. Luo, D. A. Briley, P. I. Chow, R. Su, and P.
L. Hill, "A systematic review of personality trait change through intervention," Psychol. Bull., vol. 143, no. 2, pp. 117-141, 2017. https://doi.org/10.1037/bul0000088

[43] N. R. Hill et al., "Global Prevalence of Chronic Kidney Disease - A Systematic Review and Meta-Analysis," PLoS ONES ONE, vol. 11, no. 7, pp. 1-18, 2016. https://doi.org/10.5061/dryad.3s7rd.Funding

[44] Cresswell John, [Creswell, J.] Research design Qualitati ve, Quantintative and mixed methods approach, 4 th Editi. 2014 .

[45] S. Awad, A. Saaed, N. Badarulzaman, and D. B. Mohamad, "A PROPOSED CLASSIFICATION OF THE FACTORS AFFECTING THE LEVEL OF COMPLIANCE WITH RESIDENTIAL PLANNING STANDARDS AND REGULATIONS IN DEVELOPING COUNTRIES," J. Crit. Rev., vol. 7, no. 13, pp. 4205-4213, 2020. 